\title{
Quantitative investigation of factors relevant to the T cell spot test for tuberculosis infection in active tuberculosis
}

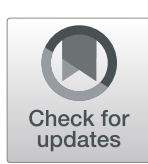

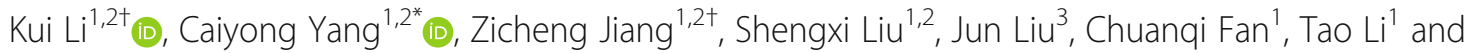
Xuemin Dong ${ }^{3}$

\begin{abstract}
Background: Previous qualitative studies suggested that the false negative rate of the $T$ cell spot test for tuberculosis infection (T-SPOT.TB) is associated with many risk factors in tuberculosis patients. However, more precise quantitative studies are lacking. The purpose of this study was to investigate the factors affecting quantified spot-forming cells (SFCs) to early secreted antigenic target $6 \mathrm{kDa}$ (ESAT-6) or culture filtrate protein $10 \mathrm{kDa}$ (CFP-10) in patients with active tuberculosis.

Methods: We retrospectively analyzed the data of 360 patients who met the inclusion criteria. Using the SFCS to ESAT6 or CFP-10 levels as dependent variables, variables with statistical significance in the univariate analysis were subjected to optimal scaling regression analysis. The combination of ESAT-6 and CFP-10 (i.e., T-SPOT.TB) was analyzed by the exact logistic regression model.

Results: The results showed that the SFCs to ESAT- 6 regression model had statistical significance $(P<0.001)$ and that previous treatment and $\mathrm{CD} 4+$ and platelet counts were its independent risk factors (all $P<0.05$ ). Their importance levels were $0.095,0.596$ and 0.100 , respectively, with a total of 0.791 . The SFCs to CFP-10 regression model also had statistical significance $(P<0.001)$; platelet distribution width and alpha-2 globulin were its independent risk factors (all $P<0.05$ ). Their importance levels were 0.287 and 0.247 , respectively, with a total of 0.534 . The quantification graph showed that quantified SFCs to ESAT-6 or CFP-10 grading had a linear correlation with risk factors. Albumin-globulin ratio, CD4+ and CD8+ were independent risk factors for false negative T-SPOT.TB (all $P<0.05$ ).

Conclusions: In T-SPOT.TB-assisted diagnosis of patients with active tuberculosis, previous treatment, decreased CD4+ and platelet count might lead to the decreased SFCS to ESAT-6, decreased alpha-2 globulin and high platelet distribution width might lead to the decreased SFCs to CFP-10, decreased albumin-globulin ratio, CD4+ and CD8+ might lead to an increase in the false negative rate of the T-SPOT.TB.
\end{abstract}

Keywords: Tuberculosis, T-SPOT.TB, IGRA, Diagnosis, Risk factors

\section{Background}

The interferon-gamma release assay (IGRA) represents one of the most important advances in the immunodiagnosis of Mycobacterium tuberculosis (MTB) infection in

\footnotetext{
* Correspondence: hbsyemclk7812@163.com

${ }^{\dagger}$ Kui Li and Zicheng Jiang contributed equally to this work.

${ }^{1}$ Department of Infectious Diseases, Ankang Central Hospital, 85 South Jinzhou Road, Ankang 725000, Shaanxi Province, China

${ }^{2}$ Department of Infectious Diseases, Ankang Central Hospital, Hubei

University of Medicine, 30 South Renmin Road, Shiyan 442000, Hubei

Province, China

Full list of author information is available at the end of the article
}

the past two decades. As a new adjuvant method for the diagnosis of MTB infection, IGRA has been widely applied and accepted clinically. In principle, IGRA determines whether the subject is infected with MTB by examination of the levels of released $\gamma$-interferon (IFN$\gamma$ ) after stimulation of whole blood or peripheral blood mononuclear cells (PBMCs) with MTB-specific antigen. This test is not affected by Bacillus Calmette-Guerin (BCG) vaccination [1], a feature that is very beneficial in countries such as China in which general BCG vaccination is practiced. Currently, the $\mathrm{T}$ cell spot test for

(c) The Author(s). 2019 Open Access This article is distributed under the terms of the Creative Commons Attribution 4.0 International License (http://creativecommons.org/licenses/by/4.0/), which permits unrestricted use, distribution, and 
tuberculosis infection (T-SPOT.TB) is the main IGRA test method; it provides intuitive and reproducible results and quantitatively reflects the number of IFN- $\gamma$ secreting cells in preparations of PBMCs [2].

IGRA still has a certain false negative rate among patients with tuberculosis (TB). Previous studies reported that negative bacteria in sputum [3-5], hypoproteinemia [6-8], combined HIV infection [4, 7, 9], anti-TB treatment $[10,11]$, medical history $[8,12]$, anemia $[6,13]$, diabetes [14], parasitic infections [13], noncavitary lesions in the lung [5], fall and winter seasons [15], increased human leukocyte antigen DRB1-0701 allele [16] and non-Hispanic white or Asian ethnicity [6, 9] are risk factors for false negative IGRA. The association between IGRA and age [3, 7-9, 12, 13, 15-18], body mass index (BMI) [12, 16] and reduced lymphocyte levels $[3,5,7,8,17,19,20]$ is inconsistent among previous studies. Some of these studies were qualitative studies with small samples and did not consider the possibility that different antigen risk factors might have confounded or biased the results. In addition, there is a lack of quantitative examination of the association between spot-forming cells (SFCs) within PBMCs and clinical and laboratory characteristics. As a result, further research is urgently needed. Our main objective based on population analysis is to identify factors associated with different antigen quantification results of T-SPOT.TB in active TB (ATB), with the goal of providing more reference evidence for the accurate application of T-SPOT.TB.

\section{Methods}

\section{Study populations}

This retrospective study analyzed 360 pathogenically positive TB patients who were hospitalized in Ankang Central Hospital, Shaanxi, China, and the data were accessed between October 1, 2016 and June 30, 2018. We collected data on 29 variables associated with five aspects, including the patients' general status, bacteriology, imaging, routine examination, protein electrophoresis and immunology. The subject screening process is illustrated in (Fig. 1).

This study was approved by the ethics committee of Ankang Central Hospital (ECACH-2016011). Informed consent was not required because the study did not put the patients at risk. Prior to analysis, the patients' identities were protected by anonymity and by the use of codes.

\section{Inclusion and exclusion criteria}

The inclusion criteria were as follows [21]: (1) the MTBspecific deoxyribonucleic acid or ribonucleic acid test was positive, and patients had suspected symptoms of TB; (2) patients had one sputum smear that was positive

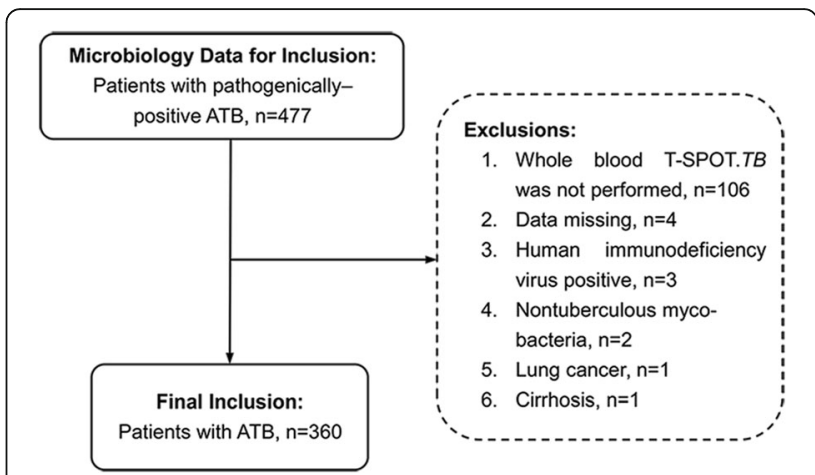

Fig. 1 Description of the sample. ATB Active tuberculosis

for acid-fast staining or positive sputum culture, and thoracic imaging showed lesions conforming to ATB and/or suspected symptoms of TB; (3) patients were subjected to the T-SPOT.TB test, and the results were accessible.

The exclusion criteria were as follows: (1) patients who were taking immunosuppressants; (2) patients who did not undergo IGRA examination; (3) patients who were positive for HIV infection; (4) patients with nontuberculous mycobacteria infection; (5) patients with combined cirrhosis; (6) patients with combined tumor.

\section{T-SPOT.TB assay}

The T-SPOT.TB diagnosis kit was provided by Shanghai Fosun Long March Medical Science Co., LTD (Oxford Immunotec Ltd., United Kingdom). Specimens were examined within $2 \mathrm{~h}$ of collection at room temperature $\left(18-25^{\circ} \mathrm{C}\right)$ in a sterile environment. (1) RPMI 1640 medium was mixed with an equal volume of a whole blood sample. (2) Three milliliters of Ficoll human lymphocyte isolation solution was added to the first centrifuge tube; $6-9 \mathrm{ml}$ of diluted whole blood was then slowly added to the solution, and the tube was centrifuged at $1000 \mathrm{x}$ g for $22 \mathrm{~min}$. (3) Approximately $5 \mathrm{ml}$ of the layer containing PBMCs was transferred to a second centrifuge tube, and the mixture was brought to a volume of $10 \mathrm{ml}$ with RPMI 1640; the tube was then inverted and centrifuged at $600 \mathrm{x}$ g for $7 \mathrm{~min}$. (4) The supernatant was discarded, the pellet was resuspended in $1 \mathrm{ml}$ of medium, and RPMI 1640 was added to bring the final volume to $10 \mathrm{ml}$. After mixing by inverting the tube, the sample was centrifuged at $350 \times \mathrm{g}$ for $7 \mathrm{~min}$. (5) The supernatant was discarded, and the pellet was resuspended in AIM-V medium at a density of $2.5 \times 10^{6}$ cells/ml. (6) Fifty microliters of negative control (ALM$\mathrm{V})$, antigen A (early secreted antigenic target $6 \mathrm{kDa}$, ESAT-6), antigen $B$ (culture filtrate protein $10 \mathrm{kDa}$, CFP10) and positive control (PHA) were added sequentially to an IFN- $\gamma$ antibody-coated microplate; $100 \mu \mathrm{l}$ of diluted cells were then added to each well, and the plate 
was placed in a $\mathrm{CO}_{2}$ incubator $\left(37^{\circ} \mathrm{C}, 5 \% \mathrm{CO}_{2}\right)$ for $20 \mathrm{~h}$. (7) After removal of the medium, each well was washed four times with $200 \mu \mathrm{l}$ of PBS and incubated with $50 \mu \mathrm{l}$ of secondary antibody working solution (1200) for $1 \mathrm{~h}$ at $2-8{ }^{\circ} \mathrm{C}$. (8) After removal of the secondary antibody, each well was washed four times with PBS, $50 \mu \mathrm{l}$ of substrate chromogen solution was added to each well, and the plate was allowed to stand for $10 \mathrm{~min}$ in the dark. The reaction was terminated by washing the plate with distilled water. (9) SFCs were automatically counted using a plate reader (ES-15, Shanghai Fosun Long March Medical Science Co., Ltd., Shanghai, China). When the counts could not be determined using the plate reader, the SFCs were manually counted using a microscope. The results were recorded and interpreted as recommended by the kit manufacturer: ESAT- 6 or CFP- $10 \geq 6$ SFCs was regarded as T-SPOT.TB positive. T-SPOT.TB was negative if both ESAT- 6 and CFP-10 were $<6$ SFCs. The test results were uncertain if there were $>10$ SFCs in the blank control well or $<20$ SFCs in the positive control well. In cases of uncertain results, blood samples were taken again for another test.

\section{Diagnosis of TB}

Sputum or body fluid specimens were first examined using Auramine O fluorescence staining (KRJ/TTR500 automatic smear staining machine, Xiangyang Courager Medical Apparatus, Xiangyang, China) and were then subjected to MTB nucleic acid amplification (RNA constant temperature amplification, Roche LightCycler 480 II Real-time PCR Cycler; Rendu Biotechnology [Shanghai, China]; PCR-fluorescence method, Applied Biosystems 7500 Real-Time PCR System; DAAN Gene of Sun Yat-sen University [Guangzhou, China]) and rapid drug tolerance gene analysis (DNA microarray chip method; CapitalBio Corporation, Chengdu, China). Finally, the specimens were subjected to MTB culture (Roche fixed culture test), bacterial species identification and drug sensitivity testing (Ratio methods, BaSo Diagnostics INC., ZHUHAI). Using the Roche solid culture as the standard and no repeated counting, bacterial load was reported in accordance with the "Diagnostic Criteria and Principles of Management of Infectious Pulmonary Tuberculosis" [21] (see Additional file 1). The laboratory meets the national P3 requirements and accepts the quality control and management of the national reference laboratory. All operators received special training in the testing methods and in operation of the apparatus.

\section{Measurement of other variables}

BMI was calculated by dividing the individual's body weight $(\mathrm{kg})$ by the square of his or her height $(\mathrm{m})$. Body weight and height were measured at the time of admission. Behavioral risk factors (such as smoking and exposure to dust) and medical history were collected by physicians. The diagnostic criteria for diabetes were random blood glucose $\geq 11.1 \mathrm{mmol} / \mathrm{L}$ or fasting blood glucose $\geq 7.0 \mathrm{mmol} / \mathrm{L}$ [22]. The severity of lung imaging was graded according to the criteria set by the $\mathrm{Na}$ tional Tuberculosis Association of America [23] (see Additional file 2). Whole blood cell counts were determined using a Sysmex XN-9000 automatic blood fluid analyzer and supporting reagents. Serum protein electrophoresis was performed with the Sebia Capillarys 2 Flex Piercing detection platform and supporting reagents (Pare Technologique Leonard de Vinci, CP8010-Lisses 91,008 EVRY CEDEX, France). Lymphocyte subsets were detected using the Mindray flow cytometer BriCyte E6 and a kit from BD.

\section{Statistical analysis}

The data were analyzed using SPSS software (version 22.0, IBM Corp., Armonk, NY, USA). Non-normally distributed data were expressed as medians and interquartile ranges. Wilcoxon's rank sum test was used to compare two-sample dichotomous variables. The rank data and measurement data were analyzed using the Spearman relationship test, and the statistically significant variables were subjected to optimal scaling regression analysis. The false negative rate of T-SPOT.TB was analyzed by the exact logistic regression model of $\mathrm{R}$ software (version 3.4.4; https://www.r-project.org). Tolerance $\geq 0.1$ is considered as collinearity between variables. The missing values of the independent variables were replaced by the series mean. Adobe Photoshop CS6 software (version $13.0 \times 32$, Adobe Systems Incorporated, San Jose, CA, USA) was used for graphing. $P<0.05$ was considered statistically significant.

\section{Results}

We recruited 360 patients with an average age of 53.00 years (ranging $36.00-66.00$ year), of whom $78.06 \%$ were male (281/360). The false negative rates of ESAT-6, CFP-10 and T-SPOT.TB were 8.61\% (31/360), 10.00 (36/ $360)$ and $3.33 \%(12 / 360)$, respectively. The true positive and false negative rates for T-SPOT.TB test in pulmonary and extra pulmonary $\mathrm{TB}$ groups are shown in Additional file 3.

Univariate analysis showed that there was statistical significance in the yes or no of previously treated cases with SFCs to ESAT-6 $(P<0.05)$. CD4+, CD8+, platelet (PLT), prealbumin, albumin, albumin-globulin ratio and beta-1 globulin were positively associated with SFCs to ESAT-6 (all $P<0.05$ ). Alpha-1 globulin was negatively associated with SFCs to ESAT-6 $(P<0.05)$. CD4+, CD8+, PLT, prealbumin, albumin and alpha-2 globulin were positively associated with SFCs to CFP-10 (all $P<0.05$ ). Age and platelet 
distribution width (PDW) were negatively associated with SFCs to CFP-10 (all $P<0.05$ ). The associations with other independent variables, including gender, sputum bacterial load and BMI, were not statistically significant (all $P>0.05$ ) (Tables 1 and 2). The differences in age and gender were not statistically significant between negative and positive T-SPOT.TB $(P>0.05)$, and prealbumin, albumin, albumin-globulin ratio, $\mathrm{CD} 4+$ and CD8+ differed significantly between the two groups $(P<0.05)$ (see Additional files 4 and 5 ).

Optimal scaling regression analysis showed that the regression models were statistically significant (SFCs to ESAT-6, adjusted R-squared $=0.147, \mathrm{~F}=7.884, P<0.001$; SFCs to CFP-10, adjusted R-squared $=0.061, F=3.890$, $P<0.001)$. Analysis of all the included factors showed that previously treated cases, CD4+ and PLT were significantly associated with SFCs to ESAT-6; their importance levels were $0.095,0.596$ and 0.100 , respectively, with a total of 0.791 . PDW and alpha-2 globulin were also significantly associated with SFCs to CFP-10; their importance levels were 0.287 and 0.247 , respectively, with a total of 0.534 . The tolerances of the included factors in the two models were $>0.1$, indicating that there was no serious collinearity among the factors and that the regression models were reliable (Table 3).

The quantification graph after variable conversion showed the following. (1) The quantified SFCs to ESAT6 grading of previously treated cases was lower than that of new cases (Fig. 2a). (2) The quantified SFCs to ESAT6 grading increased as CD4+ and PLT increased (Fig. 2b and c). (3) The quantified SFCs to CFP-10 grading increased as PDW and alpha-2 globulin increased (Fig. 2d and e).

Exact logistic regression analysis showed that albuminglobulin ratio, $\mathrm{CD} 4+$ and $\mathrm{CD} 8+$ were independent risk factors for false negative T-SPOT.TB (all $P<0.05$ ) (Table 4).

\section{Discussion}

In ATB, the number of MTB increases and the number as well as amount of secretion of activated MTB-specific effector cells increases with it. Relevant studies have also shown that the level of SFCs differs between latent tuberculosis infection (LTBI) and ATB [24], and between before and after anti-tuberculosis treatment [25, 26], which indicates that it could serve as a complementary approach to make a distinction between ATB and LTBI and to predict the progress of LTBI into ATB. Seeing that the existence of T-SPOT.TB false negative was related to SFCs and tuberculosis activity level, the study on factors influencing quantitative changes in SFCs would provide reference to the improvement of $\mathrm{T}$ SPOT.TB detection sensitivity and the development of its field of application.
In this study, the observed false negative rate of $\mathrm{T}$ SPOT.TB was lower than the T-SPOT.TB false negative rate of $6.74 \%(61 / 905)$ reported in a previous study [27]. This discrepancy may be due to inconsistencies in case inclusion criteria and to the existence of different comorbidities. Children or patients who are taking immunosuppressants may impact the uncertain outcomes. In the current study, children ( $0-14$ years old) accounted for $0.83 \%$ (3/360), and patients who were using immunosuppressants were excluded, so they had minimal impact on our results.

This study showed that the SFCs to ESAT-6 of previously treated cases was significantly lower than that of new cases. The causes may include the following. (1) As the disease progresses, the cellular immune function of the body further declines, and the corresponding immune reactions are gradually weakened. Cell activation or immunosuppression is further aggravated, and this aggravation weakens the immune response of the $\mathrm{T}$ lymphocytes to MTB and leads to a reduced number of cells releasing IFN- $\gamma$. (2) MTB may directly and continuously downregulate helper $\mathrm{T}$ cells (Th1), leading to reduced function of Th1 in secreting IFN- $\gamma$ [28]. (3) Following anti-TB treatment, the MTB is gradually cleared from the body. However, the TB antigen-specific effector $\mathrm{T}$ cells are also reduced in number or even disappear, which may lead to a decline in SFCs to ESAT-6. This outcome is consistent with a previous study [29].

In this study, $17.50 \%$ (63/360) of the patients had extra pulmonary tuberculosis, and we did not find an association between pulmonary tuberculosis and extrapulmonary tuberculosis in the T-SPOT.TB results (see Additional file 3). Additionally, another study reported increased activation frequency of regulatory $\mathrm{T}$ cells and $\mathrm{T}$ lymphocytes in patients with extrapulmonary tuberculosis [30], indicating that this relationship cannot be replaced by each other in the complex immune regulatory network of the body.

Age and diabetes had a marginally significant effect in quantitative analysis, while there was no effect in qualitative analysis, which is not consistent with previous studies [14-18]. This might be because we included parameters that are more associated with T-SPOT.TB, age and diabetes were excluded due to their limited contribution.

BMI is an alternative indicator of body's nutritional status. BMI had no effect in our study whether it was quantitative, qualitative or two extreme cases (BMI $<16.00 \mathrm{~kg} / \mathrm{m}^{2}$ accounted for $10.73 \%$ (38/354) and $B M I \geq 25.00 \mathrm{~kg} / \mathrm{m}^{2}$ accounted for $4.00 \%$ (14/354) (see Additional file 6)). Unfortunately, we lacked data for $\mathrm{BMI} \geq 25.00 \mathrm{~kg} / \mathrm{m}^{2}$ in the results of false negative $\mathrm{T}$ SPOT.TB. This finding is inconsistent with some previous studies $[12,16]$, which may be related to variable type, 
Table 1 Univariate analysis of SFCS to ESAT-6 or CFP-10 (nominal and ordinal variables)

\begin{tabular}{|c|c|c|c|c|c|c|c|}
\hline \multirow[t]{2}{*}{ Variable } & \multirow[t]{2}{*}{$\mathrm{N}$} & \multicolumn{3}{|l|}{ SFCs to ESAT-6 } & \multicolumn{3}{|l|}{ SFCs to CFP-10 } \\
\hline & & SFCs/250000PBMCs & Test value & $P$ value & SFCs/250000PBMCs & Test value & $P$ value \\
\hline Total & 360 & $69.0(24.3-148.3)$ & & & $83.5(23.0-218.3)$ & & \\
\hline \multicolumn{8}{|l|}{ Sex } \\
\hline Female & 79 & $87.0(42.0-155.0)$ & & & $97.0(42.0-200.0)$ & & \\
\hline Male & 281 & $66.0(22.5-134.5)$ & $Z=12,681.5$ & 0.053 & $82.0(21.0-227.0)$ & $Z=11,627.5$ & 0.518 \\
\hline \multicolumn{8}{|l|}{ Smoking $^{a}$} \\
\hline No & 147 & $71.0(37.0-143.0)$ & & & $92.0(29.0-234.0)$ & & \\
\hline Yes & 213 & $66.0(20.0-150.0)$ & $Z=14,353.0$ & 0.180 & $82.0(21.5-205.5)$ & $Z=15,138.0$ & 0.594 \\
\hline \multicolumn{8}{|l|}{ Dust exposure ${ }^{a}$} \\
\hline No & 257 & $69.0(27.0-146.5)$ & & & $82.0(22.0-200.0)$ & & \\
\hline Yes & 103 & $59.0(19.0-150.0)$ & $Z=12,438.5$ & 0.372 & $85.0(28.0-237.0)$ & $Z=13,966.0$ & 0.413 \\
\hline \multicolumn{8}{|l|}{ Previously treated cases } \\
\hline $\mathrm{No}^{\mathrm{b}}$ & 257 & $74.0(28.5-150.0)$ & & & $91.0(23.0-235.5)$ & & \\
\hline Yes $^{c}$ & 103 & $54.0(13.0-97.0)$ & $Z=10,233.0$ & 0.001 & $65.0(23.0-200.0)$ & $Z=12,289.5$ & 0.289 \\
\hline \multicolumn{8}{|l|}{ Cavitation } \\
\hline No & 137 & $72.0(26.5-144.0)$ & & & $91.0(18.0-200.0)$ & & \\
\hline Yes & 223 & $67.0(24.0-150.0)$ & $Z=15,093.0$ & 0.849 & $82.0(24.0-257.0)$ & $Z=15,772.5$ & 0.604 \\
\hline \multicolumn{8}{|l|}{ Extrapulmonary tuberculosis } \\
\hline No & 297 & $69.0(24.0-150.0)$ & & & $82.0(23.0-200.0)$ & & \\
\hline Yes & 63 & $66.0(25.0-114.0)$ & $Z=8997.5$ & 0.633 & $121.0(24.0-300.0)$ & $Z=9996.5$ & 0.393 \\
\hline \multicolumn{8}{|l|}{ Diabetes mellitus } \\
\hline No & 330 & $70.0(24.8-150.0)$ & & & $87.0(24.0-220.3)$ & & \\
\hline Yes & 30 & $38.5(22.0-89.5)$ & $Z=3920.0$ & 0.059 & $49.5(7.8-216.0)$ & $Z=4321.0$ & 0.249 \\
\hline \multicolumn{8}{|l|}{ Drug-resistant tuberculosis } \\
\hline No & 327 & $69.0(25.0-150.0)$ & & & $85.0(23.0-220.0)$ & & \\
\hline Yes & 33 & $65.0(15.5-134.5)$ & $Z=5181.0$ & 0.707 & $71.0(25.0-199.0)$ & $Z=5409.0$ & 0.981 \\
\hline \multicolumn{8}{|l|}{ Stage $^{d}$} \\
\hline Minimal/Mild & 2 & $77.5(0.0-77.50)$ & & & $85.5(22.0-85.5)$ & & \\
\hline Moderate & 143 & $78.0(38.0-150.0)$ & & & $97.0(41.0-264.0)$ & & \\
\hline Advanced & 215 & $64.0(22.0-126.0)$ & SRCC $=-0.095$ & 0.071 & $82.0(15.0-211.0)$ & $\mathrm{SRCC}=0.000$ & 0.995 \\
\hline \multicolumn{8}{|l|}{ Grade $^{e}$} \\
\hline DNA/RNA positive & 80 & $68.0(27.3-99.5)$ & & & $84.0(22.5-251.8)$ & & \\
\hline The number of colony & 24 & $104.0(51.8-203.5)$ & & & $132.5(24.8-262.5)$ & & \\
\hline $1+$ & 102 & $67.0(21.8-150.0)$ & & & $77.0(22.8-205.0)$ & & \\
\hline $2+$ & 50 & $59.5(25.5-142.3)$ & & & $81.0(21.3-291.8)$ & & \\
\hline $3+$ & 70 & $69.0(24.5-150.0)$ & & & $86.0(26.8-200.0)$ & & \\
\hline $4+$ & 34 & $65.5(30.3-126.8)$ & $\mathrm{SRCC}=-0.075$ & 0.158 & $59.5(19.3-154.8)$ & $\mathrm{SRCC}=-0.029$ & 0.587 \\
\hline
\end{tabular}

Data are presented as $\mathrm{N}$, median (interquartile range). There were no missing values

a: Smoking or dust exposure for at least 3 months before a diagnosis of pulmonary tuberculosis

b: New cases are defined as not starting anti-TB treatment or being on anti-TB treatment for $<1$ month

c: Previously treated cases are defined as those anti-TB treated $\geq 1$ month in the past

d: The staging standard of National Tuberculosis Association of the United States of America

e: Smear grading before treatment

CFP-10 Culture filtrate protein $10 \mathrm{kDa}$, DNA Deoxyribonucleic acid, ESAT-6 Early secreted antigenic target $6 \mathrm{kDa}$, PBMCs Peripheral blood mononuclear cells, RNA Ribonucleic acid, SFCs Spot-forming cells, SRCC Spearman's rho correlation coefficient, $Z$ Wilcoxon's rank sum test 
Table 2 Univariate analysis of SFCs to ESAT-6 or CFP-10 (numeric variables)

\begin{tabular}{|c|c|c|c|c|c|c|c|}
\hline \multirow[t]{2}{*}{ Variable } & \multicolumn{2}{|c|}{ Missing data } & \multirow{2}{*}{$\begin{array}{l}\text { Median } \\
\text { (interquartile } \\
\text { range) }\end{array}$} & \multicolumn{2}{|c|}{ SFCS to ESAT-6 } & \multicolumn{2}{|c|}{ SFCs to CFP-10 } \\
\hline & $\mathrm{N}$ & $(\%)$ & & SRCC & $P$ value & SRCC & $P$ value \\
\hline Age, years & 0 & $(00.0)$ & $53.0(36.0-66.0)$ & -0.102 & 0.054 & $-0.107^{b}$ & 0.042 \\
\hline Body mass index, $\mathrm{kg} / \mathrm{m}^{2}$ & 6 & $(1.7)$ & $19.1(17.6-21.2)$ & 0.030 & 0.565 & 0.013 & 0.801 \\
\hline Duration of symptoms, days & 0 & $(00.0)$ & $90.0(30.0-496.3)$ & -0.073 & 0.165 & 0.025 & 0.630 \\
\hline Hemoglobin, g/L & 0 & $(00.0)$ & $118.0(105.0-134.8)$ & 0.034 & 0.518 & 0.016 & 0.765 \\
\hline Platelet, $\times 10^{9} / \mathrm{L}$ & 0 & $(00.0)$ & $258.0(191.0-320.8)$ & $0.173^{c}$ & 0.001 & $0.186^{c}$ & $<0.001$ \\
\hline Platelet distribution width, fL & 0 & $(00.0)$ & $14.0(11.7-16.2)$ & -0.090 & 0.089 & $-0.116^{b}$ & 0.027 \\
\hline Erythrocyte sedimentation rate, $\mathrm{mm} / \mathrm{H}$ & 32 & $(8.9)$ & $49.9(28.3-69.0)$ & -0.070 & 0.184 & -0.028 & 0.594 \\
\hline Prealbumin, mg/L & 39 & $(10.8)$ & $143.6(84.3-184.8)$ & $0.187^{c}$ & $<0.001$ & $0.104^{b}$ & 0.050 \\
\hline Albumin, $g / L$ & 1 & $(0.3)$ & $31.9(27.6-36.5)$ & $0.159^{c}$ & 0.002 & $0.108^{b}$ & 0.040 \\
\hline Globulin, g/L & 5 & $(1.4)$ & $32.6(28.9-36.1)$ & 0.014 & 0.795 & 0.049 & 0.356 \\
\hline Albumin-globulin ratio & 5 & (1.4) & $1.0(0.8-1.2)$ & $0.105^{b}$ & 0.047 & 0.054 & 0.303 \\
\hline Alpha-1 globulin, g/L & 40 & $(11.1)$ & $4.9(3.7-5.6)$ & $-0.122^{b}$ & 0.020 & -0.077 & 0.146 \\
\hline Alpha-2 globulin, g/L & 40 & $(11.1)$ & $7.6(6.5-8.6)$ & 0.091 & 0.085 & $0.141^{c}$ & 0.007 \\
\hline Beta-1 globulin, g/L & 40 & $(11.1)$ & $3.7(3.3-4.1)$ & $0.111^{b}$ & 0.036 & 0.058 & 0.270 \\
\hline Beta-2 globulin, g/L & 40 & $(11.1)$ & $3.7(3.2-4.1)$ & 0.034 & 0.514 & 0.063 & 0.233 \\
\hline Gamma globulin, g/L & 40 & $(11.1)$ & $13.0(10.4-14.7)$ & 0.012 & 0.823 & 0.014 & 0.797 \\
\hline CD4+ T lymphocytes, cells/ $\mu \mathrm{L}$ & 89 & $(24.7)$ & $302.0(203.0-445.0)$ & $0.391^{c}$ & $<0.001$ & $0.230^{c}$ & $<0.001$ \\
\hline CD8+ T lymphocytes, cells $/ \mu \mathrm{L}$ & 89 & $(24.7)$ & $253.0(164.0-379.0)$ & $0.291^{c}$ & $<0.001$ & $0.190^{c}$ & $<0.001$ \\
\hline $\mathrm{CD} 4+$ to $\mathrm{CD} 8+$ ratio & 89 & $(24.7)$ & $1.2(0.9-1.7)$ & 0.049 & 0.354 & -0.042 & 0.425 \\
\hline
\end{tabular}

${ }^{a}$ : Data are presented as the value of variable

b. Correlation is significant at the 0.05 level (2-tailed)

c: Correlation is significant at the 0.01 level (2-tailed)

CFP-10 Culture filtrate protein $10 \mathrm{kDa}$, ESAT-6 Early secreted antigenic target $6 \mathrm{kDa}$, SFCs Spot-forming cells, SRCC Spearman's rho correlation coefficient

BMI data distribution and the different location and social environment of subjects.

It was found in this study that SFCs to ESAT-6 or CFP-10 were positively correlated with the number of PLT, but negatively correlated with PDW. Finally, this correlation only maintained between PLT and SFCs to ESAT-6, PDW and SFCs to CFP-10 in the multivariate analysis. PLT might stimulate $\mathrm{T}$ lymphocyte adhesion by secreting RANTES (regulated on activation, normal Tcell expressed and secreted, also known as CCL5), a key chemical inducer, so as to regulate $\mathrm{T}$ lymphocytes [31, 32]. PDW is a parameter that reflects the variation in PLT volume, The $\alpha$-granules $[33,34]$ and P-selectin involved in immuno regulation in PLT were the main factors affecting PDW. It is possible that the number of PLT with small volumes and lacking P-selectin leads to higher bacterial load in the lungs [35], when the body is stimulated by the more MTB antigen, it produced more SFCs to CFP-10. PLT and PDW showed the trend above in the T-SPOT.TB false negative analysis, but there was no statistical significance, which was inconsistent with the research of Kim et al. [36], and it might be related to the small number of false negative cases in this study.
The preliminary studies showed that, the decrease of albumin [37] and the increase of alpha-2 globulin [38] could be seen in the patients with pulmonary tuberculosis, which just reduced the albumin-globulin ratio, thereby affecting the body's immune function, and possible mechanisms might be: (1) Malnutrition may impair the functions of antigen presenting cells [39] and inhibit glucose metabolism-dependent $\mathrm{T}$ cell activation [40, 41]. (2) Alpha-2 globulin mainly includes haptoglobin, ceruloplasmin, and alpha-2 macroglobulin. Haptoglobin and ceruloplasmin increased as acute phase reaction proteins; alpha- 2 macroglobulin increased in a compensatory manner to maintain plasma colloid osmotic pressure due to hypoalbuminemia. Nevertheless, in the final analysis, it was alpha-2 globulin that affected SFCs to CFP-10, rather than albumin, which could not be fully explained by the mechanism of compensatory increase; albumin-globulin ratio showed more potential as an indicator of nutritional status and chronic infection, and all of these problems deserve further studies.

It was found in the multivariate analysis that, $\mathrm{CD} 4+$ was positively correlated with SFCs to ESAT-6, and CD4+ and $\mathrm{CD} 8+$ were positively correlated with false negative $\mathrm{T}$ SPOT.TB; while, CD8+ showed no correlation with SFCs to ESAT-6 or CFP-10. The quantification graph following 
Table 3 Optimal scale regression analysis of SFCs to ESAT-6 or CFP-10

\begin{tabular}{|c|c|c|c|c|c|c|c|c|}
\hline \multirow[t]{2}{*}{ Variable } & \multirow[t]{2}{*}{ Beta } & \multirow{2}{*}{$\begin{array}{l}\text { Standardized } \\
\text { coefficients Std.Error }\end{array}$} & \multirow[t]{2}{*}{$d f$} & \multirow[t]{2}{*}{$\mathrm{F}$} & \multirow[t]{2}{*}{ Sig. } & \multicolumn{2}{|l|}{ Tolerance } & \multirow[t]{2}{*}{ Importance } \\
\hline & & & & & & After transformation & Before transformation & \\
\hline \multicolumn{9}{|l|}{ SFCs to ESAT- $6^{\text {a }}$} \\
\hline Previously treated cases & 0.103 & 0.046 & 1 & 5.110 & 0.024 & 0.948 & 0.948 & 0.095 \\
\hline Platelet, $\times 10^{9} / \mathrm{L}$ & 0.115 & 0.054 & 1 & 4.471 & 0.035 & 0.818 & 0.818 & 0.100 \\
\hline Prealbumin, mg/L & 0.043 & 0.072 & 1 & 0.366 & 0.545 & 0.492 & 0.492 & 0.040 \\
\hline Albumin, $g / L$ & 0.080 & 0.094 & 1 & 0.738 & 0.391 & 0.253 & 0.253 & 0.076 \\
\hline Albumin-globulin ratio & -0.075 & 0.082 & 1 & 0.819 & 0.366 & 0.274 & 0.274 & -0.039 \\
\hline Alpha-1 globulin, g/L & -0.092 & 0.056 & 1 & 2.630 & 0.106 & 0.725 & 0.725 & 0.072 \\
\hline Beta-1 globulin, g/L & -0.016 & 0.062 & 1 & 0.067 & 0.796 & 0.617 & 0.617 & -0.008 \\
\hline CD4+ T lymphocytes, cells/ $\mu \mathrm{L}$ & 0.277 & 0.075 & 1 & 13.539 & 0.000 & 0.598 & 0.598 & 0.596 \\
\hline CD8+ T lymphocytes, cells/ $\mu \mathrm{L}$ & 0.048 & 0.063 & 1 & 0.588 & 0.444 & 0.658 & 0.658 & 0.069 \\
\hline \multicolumn{9}{|l|}{ SFCs to CFP-10 } \\
\hline Age, years & -0.022 & 0.057 & 1 & 0.153 & 0.696 & 0.867 & 0.867 & 0.018 \\
\hline Platelet, $\times 10^{9} / \mathrm{L}$ & 0.027 & 0.068 & 1 & 0.161 & 0.688 & 0.634 & 0.634 & 0.047 \\
\hline Platelet distribution width, fL & -0.149 & 0.058 & 1 & 6.549 & 0.011 & 0.701 & 0.701 & 0.287 \\
\hline Prealbumin, mg/L & -0.032 & 0.076 & 1 & 0.179 & 0.672 & 0.539 & 0.539 & -0.021 \\
\hline Albumin, $g / L$ & 0.118 & 0.070 & 1 & 2.830 & 0.093 & 0.488 & 0.488 & 0.131 \\
\hline Alpha-2 globulin, g/L & 0.133 & 0.049 & 1 & 7.464 & 0.007 & 0.917 & 0.917 & 0.247 \\
\hline CD4+ T lymphocytes, cells/ $\mu \mathrm{L}$ & 0.115 & 0.071 & 1 & 2.648 & 0.105 & 0.608 & 0.608 & 0.236 \\
\hline CD8+ T lymphocytes, cells/ $\mu \mathrm{L}$ & 0.031 & 0.063 & 1 & 0.245 & 0.621 & 0.652 & 0.652 & 0.055 \\
\hline
\end{tabular}

a: $\mathrm{R}$ Square $=0.169 ;$ Adjusted $\mathrm{R}$ Square $=0.147 ; \mathrm{F}=7.884 ; P<0.001$

b: $\mathrm{R}$ Square $=0.081 ;$ Adjusted R Square $=0.061 ; \mathrm{F}=3.890 ; P<0.001$

CFP-10 Culture filtrate protein $10 \mathrm{kDa}$, ESAT-6 Early secreted antigenic target $6 \mathrm{kDa}$, SFCs Spot-forming cells

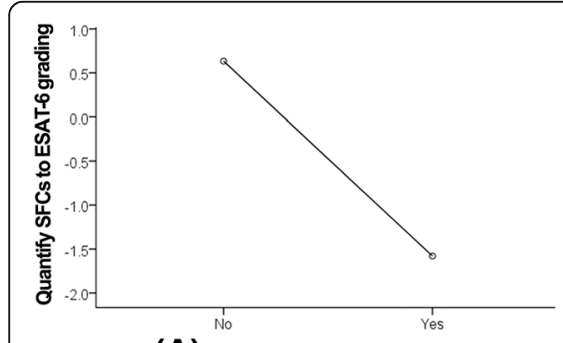

(A) Previously treated cases

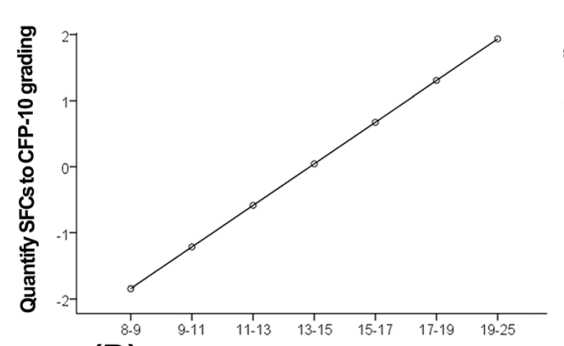

(D) Platelet distribution width grading

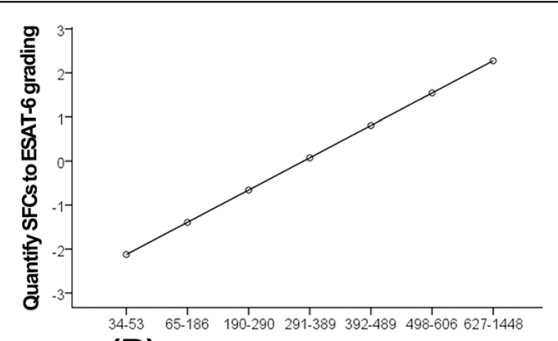

(B) CD4+ T-lymphocytes grading

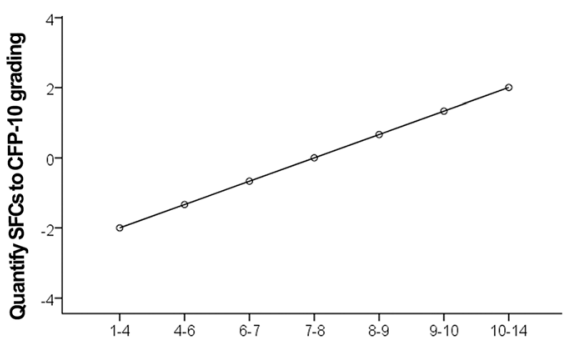

(E) Alpha-2 globulin grading

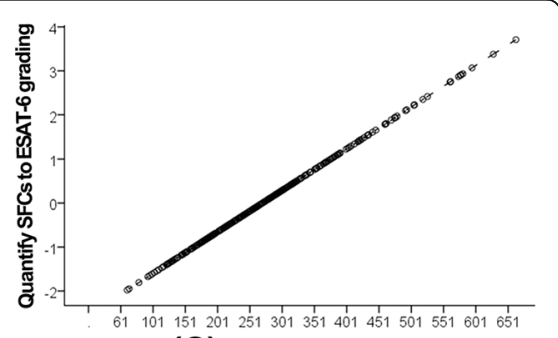

(C) Platelet grading

Fig. 2 Conversion graph between the quantified values of the independent and dependent variables. The abscissa (x-axis) represents the value before variable conversion, and the ordinate (y-axis) represents the quantified SFCs to ESAT-6 or CFP-10 grading. a Patients with a history of previous treatment showed decreased SFCs to ESAT-6 grading. $\mathbf{b}$ Quantified SFCS to ESAT-6 grading increased with an increase in the number of CD4+ T lymphocytes. c Quantified SFCs to ESAT-6 grading increased with an increase in the number of PLT. d Quantified SFCS to CFP-10 grading increased with an increase in PDW grading. e Quantified SFCs to CFP-10 grading increased with an increase in alpha-2 globulin grading. CFP-10 Culture filtrate protein $10 \mathrm{kDa}$, ESAT-6 Early secreted antigenic target $6 \mathrm{kDa}$, SFCs Spot-forming cells 
Table 4 Exact logistic regression analysis of false negative T-SPOT.TB

\begin{tabular}{|c|c|c|c|c|c|c|}
\hline \multirow[t]{2}{*}{ Variable } & \multirow[t]{2}{*}{ Estimate } & \multirow{2}{*}{$\begin{array}{l}P \\
\text { value }\end{array}$} & \multirow{2}{*}{$\begin{array}{l}\text { Standard } \\
\text { error for } \\
p \text {-value }\end{array}$} & \multirow{2}{*}{$\begin{array}{l}\text { Simulation } \\
\text { sample } \\
\text { size for } \\
\text { Monte } \\
\text { Carlo } \\
\end{array}$} & \multicolumn{2}{|c|}{$95 \%$ confidence intervals for parameters } \\
\hline & & & & & Lower & Upper \\
\hline Joint $^{\mathrm{a}}$ & NA & 0.873 & 0.015 & 8300 & NA & NA \\
\hline Prealbumin & -0.126 & 0.740 & 0.037 & 1205 & -1.525 & 1.359 \\
\hline Albumin & 0.813 & 0.133 & 0.018 & 3414 & -0.252 & 2.585 \\
\hline Albumin-globulin ratio & 0.880 & 0.035 & 0.009 & 4866 & 0.008 & 2.262 \\
\hline CD4+ T lymphocytes & 0.551 & 0.028 & 0.008 & 3491 & 0.059 & 1.196 \\
\hline CD8+ T lymphocytes & 0.498 & 0.035 & 0.010 & 2724 & -0.033 & 1.324 \\
\hline
\end{tabular}

${ }^{a}$ : It represents a test that all the parameters for the exact statement are simultaneously equal to zero in addition to the tests of the individual parameters NA Not applicable

variable conversion showed that increased $\mathrm{CD} 4+$ counts were associated with higher SFCs to ESAT-6 grading, and the importance level was relatively high, suggesting that CD4+ count is a main factor affecting SFCs to ESAT-6. It also suggests that $\mathrm{CD} 4+$ cells may play a more important role in MTB infection than CD8+ cells [42]. This finding is inconsistent with a previous study in which the immune status of the subject had minimal effect on IGRA-ELISPOT test results [43] but is consistent with the study of Zhang et al. [5]. This may be related to one or more of the following factors. (1) When a patient infected with TB is immunized, large numbers of lymphocytes accumulate at the lesion, leading to a decrease in the number of lymphocytes in the peripheral circulation and a reduction in the number of active $\mathrm{T}$ lymphocytes; this eventually leads to reduced numbers of SFCs in the T-SPOT.TB test. (2) SFCs to ESAT-6 is more closely associated with the transcription and expression of IFN- $\gamma$ by T lymphocytes [44]. (3) During immunization, CD4+ T cells preferentially release interferon, whereas $\mathrm{CD} 8+\mathrm{T}$ cells preferentially lyse antigen-presenting cells [45]. Further study and analysis are required to determine the importance of changes in the number of $\mathrm{CD} 4+\mathrm{T}$ lymphocytes in this process.

The limitations of this study are as follows. First, the amount of information available for interpreting $\mathrm{T}$ SPOT.TB variation was low, and other unknown factors remain to be investigated. Second, unlike demographic, clinical and laboratory characteristics, the genetic causes of false negative T-SPOT.TB results cannot be studied. Finally, there were limited cases with false negative T-SPOT.TB, so that its results were less reliable and more samples are needed for further studies. However, the quantitative and qualitative analysis in this study showed that, CD4+ and serum protein affected the detection results of T-SPOT.TB in ATB patients, and the correlation between PDW, alpha-2 globulin and SFCs to CFP-10 was reported for the first time.

\section{Conclusions}

In T-SPOT.TB-assisted diagnosis of patients with ATB, previous treatment, CD4+ and PLT are factors affecting SFCs to ESAT-6, and PDW and alpha-2 globulin are factors affecting SFCs to CFP-10. Albumin-globulin ratio, $\mathrm{CD} 4+$ and $\mathrm{CD} 8+$ are independent risk factors for false negative T-SPOT.TB. The influence factors for these three are different. Detailed assessment of these factors may help us accurately understand the diagnosis of $\mathrm{TB}$ using T-SPOT.TB.

\section{Additional files}

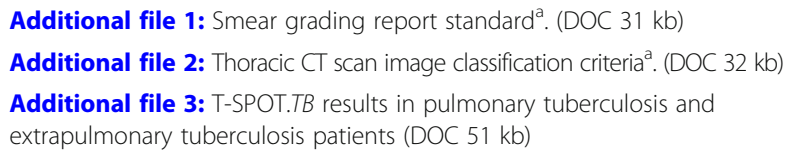

Additional file 4: Comparison of different influencing factors among tuberculosis patients with negative and positive T-SPOT.TB (dichotomy and grade variables) (DOC $105 \mathrm{~kb}$ )

Additional file 5: Comparison of different influencing factors among tuberculosis patients with negative and positive T-SPOT.TB (numeric variables) (DOC $80 \mathrm{~kb}$ )

Additional file 6: Results of T-SPOT.TB between the two extreme BMI (DOC $41 \mathrm{~kb}$ )

\section{Abbreviations \\ ATB: Active tuberculosis; BCG: Bacillus Calmette-Guerin vaccination; BMI: Body mass index; CFP-10: Culture filtrate protein $10 \mathrm{kDa}$; DNA: Deoxyribonucleic acid; ESAT-6: Early secreted antigenic target 6 kDa; HIV: Human immunodeficiency virus; IFN- $\gamma$ : Released $\gamma$-interferon; IGRA: Interferon-gamma release assay; MTB: Mycobacterium tuberculosis; PBMCs: Peripheral blood mononuclear cells; PDW: Platelet distribution width; PLT: Platelet; RNA: Ribonucleic acid; SFCs: Spot-forming cells; SRCC: Spearman's rho correlation coefficient; TB: Tuberculosis; Th1: Helper T cells; T-SPOT.TB: T cell spot test for tuberculosis infection}

\section{Acknowledgments}

American Journal Experts (Durham, North Carolina) provided assistance in translating the manuscript. 


\section{Authors' contributions}

$Y C$ and LK designed the research; LK, LS, FC and LT collected the data; $L$ and. DX supported the data; LK, JZ and YC analyzed the data; YC and LK wrote. The manuscript; and YC supervised the research. All authors have read and. Agreed with the final manuscript.

\section{Funding}

The authors received no specific funding for this work.

\section{Availability of data and materials}

The datasets used and/or analyzed during the current study are available from the corresponding author on reasonable request.

\section{Ethics approval and consent to participate}

This study was approved by the Ethics Committee of the Ankang Central Hospital (ECACH-2016011). The patient's informed written consent to analysis of their medical records was waived due to the retrospective nature of this study. No further permission from the hospital was required.

\section{Consent for publication}

Not applicable

\section{Competing interests}

The authors declare that they have no competing interests.

\section{Author details}

'Department of Infectious Diseases, Ankang Central Hospital, 85 South Jinzhou Road, Ankang 725000, Shaanxi Province, China. ${ }^{2}$ Department of Infectious Diseases, Ankang Central Hospital, Hubei University of Medicine, 30 South Renmin Road, Shiyan 442000, Hubei Province, China. ${ }^{3}$ Laboratory of Molecular Pathology and Tuberculosis Diseases, Ankang Central Hospital, 85 South Jinzhou Road, Ankang 725000, Shaanxi Province, China.

Received: 14 March 2019 Accepted: 23 July 2019

Published online: 29 July 2019

\section{References}

1. Doan TN, Eisen DP, Rose MT, Slack A, Stearnes G, McBryde ES. Interferongamma release assay for the diagnosis of latent tuberculosis infection: a latentclass analysis. PLoS One. 2017;12(11):e0188631.

2. Czerkinsky CC, Nilsson LA, Nygren H, Ouchterlony O, Tarkowski A. A solidphase enzyme-linked immunospot (ELISPOT) assay for enumeration of specific antibody-secreting cells. J Immunol Methods. 1983;65(1-2):109-21.

3. Yang C, Zhang S, Yao L, Fan L. Evaluation of risk factors for false-negative results with an antigen-specific peripheral blood-based quantitative T cell assay (T-SPOT ${ }^{\oplus}$. TB) in the diagnosis of active tuberculosis: a large-scale retrospective study in China. J Int Med Res. 2018;46(5):1815-25.

4. Oni T, Patel J, Gideon HP, Seldon R, Wood K, Hlombe Y, et al. Enhanced diagnosis of HIV-1-associated tuberculosis by relating T-SPOT.TB and CD4 counts. Eur Respir J. 2010;36(3):594-600.

5. Zhang J, Sun J, Li Y, Wang Y, Sun XH, Ma JH, et al. Clinical analysis of positive T-SPOT. TB in 1873 cases with active tuberculosis. Chin J Antituberc. 2015;37(7):778-83.

6. Sharninghausen JC, Shapiro AE, Koelle DM, Kim HN. Risk factors for indeterminate outcome on interferon gamma release assay in non-US-born persons screened for latent tuberculosis infection. Open Forum Infect Dis. 2018;5(8):ofy184

7. Kobashi Y, Sugiu T, Mouri K, Obase Y, Miyashita N, Oka M. Indeterminate results of QuantiFERON TB-2G test performed in routine clinical practice. Eur Respir J. 2009;33(4):812-5.

8. Cho K, Cho E, Kwon S, Im S, Sohn I, Song S, et al. Factors associated with indeterminate and false negative results of QuantiFERON-TB gold in-tube test in active tuberculosis. Tuberc Respir Dis (Seoul). 2012;72(5):416-25.

9. Nguyen DT, Teeter LD, Graves J, Graviss EA. Characteristics associated with negative interferon- $\gamma$ release assay results in culture-confirmed tuberculosis patients, Texas, USA, 2013-2015. Emerg Infect Dis. 2018;24(3):534-40.

10. Bosshard V, Roux-Lombard P, Perneger T, Metzger M, Vivien R, Rochat T, et al. Do results of the T-SPOT. TB interferon-gamma release assay change after treatment of tuberculosis? Respir Med. 2009;103(1):30-4.
11. Park IN, Shim TS. Qualitative and quantitative results of interferon- $\gamma$ release assays for monitoring the response to anti-tuberculosis treatment. Korean J Intern Med. 2016;32(2):302-8.

12. Pan LP, Jia HY, Liu F, Sun HS, Gao MQ, Du FJ, et al. Risk factors for falsenegative T-SPOT.TB assay results in patients with pulmonary and extrapulmonary TB. J Inf Secur. 2015;70(4):367-80.

13. Banfield S, Pascoe E, Thambiran A, Siafarikas A, Burgner D. Factors associated with the performance of a blood-based interferon- $\gamma$ release assay in diagnosing tuberculosis. PLoS One. 2012;7(6):e38556.

14. Faurholt-Jepsen D, Aabye MG, Jensen AV, Range N, Praygod G, Jeremiah K, et al. Diabetes is associated with lower tuberculosis antigen-specific interferon gamma release in Tanzanian tuberculosis patients and nontuberculosis controls. Scand J Infect Dis. 2014;46(5):384-91.

15. Beffa P, Zellweger A, Janssens JP, Wrighton-Smith P, Zellweger JP. Indeterminate test results of T-SPOT.TB performed under routine field conditions. Eur Respir J. 2008;31(4):842-6.

16. Hang NT, Lien LT, Kobayashi N, Shimbo T, Sakurada S, Thuong PH, et al. Analysis of factors lowering sensitivity of interferon- $\gamma$ release assay for tuberculosis. PLoS One. 2011;6(8):e23806.

17. Kwon YS, Kim YH, Jeon K, Jeong BH, Ryu YJ, Choi JC, et al. Factors that predict negative results of QuantiFERON-TB gold in-tube test in patients with culture-confirmed tuberculosis: a multicenter retrospective cohort study. PLoS One. 2015;10(6):e0129792.

18. de Visser V, Sotgiu G, Lange C, Aabye MG, Bakker M, Bartalesi F, et al. Falsenegative interferon- $y$ release assay results in active tuberculosis: a TBNET study. Eur Respir J. 2015;45(1):279-83.

19. Kobashi Y, Mouri K, Yagi S, Obase Y, Miyashita N, Okimoto N, et al. Clinical utility of the QuantiFERON TB-2G test for elderly patients with active tuberculosis. Chest. 2008;133(5):1196-202.

20. Lee YM, Kim SM, Park SJ, Park KH, Lee SO, Choi SH, et al. Indeterminate TSPOT.TB test results in patients with suspected extrapulmonary tuberculosis in routine clinical practice. Infect Chemother. 2013;45(1):44-50.

21. The State Bureau of Quality and Technical Supervision, Ministry of Health of the People's Republic of China. Diagnostic criteria and principles of management of infectious pulmonary tuberculosis (GB15987-1995). http:// www.nhc.gov.cn/wjw/s9491/201212/34117.shtml.

22. American Diabetes Association. Standards of medical care in diabetes-2014. Diabetes Care. 2014;37:S14-80

23. Seaton A, Seaton D, Leitch AG. Crofton and Douglas's respiratory diseases. In: Leitch AG, editor. Pulmonary tuberculosis: clinical features. 4th ed. Oxford: Blackwell Press; 1989. p. 409-10.

24. Janssens JP, Roux-Lombard P, Perneger T, Metzger M, Vivien R, Rochat T. Quantitative scoring of an interferon-gamma assay for differentiating active from latent tuberculosis. Eur Respir J. 2007;30(4):722-8.

25. Aiken AM, Hill PC, Fox A, McAdam KP, Jackson-Sillah D, Lugos MD, et al. Reversion of the ELISPOT test after treatment in Gambian tuberculosis cases. BMC Infect Dis. 2006;6:66.

26. Carrara S, Vincenti D, Petrosillo N, Amicosante M, Girardi E, Goletti D. Use of a T cell-based assay for monitoring efficacy of antituberculosis therapy. Clin Infect Dis. 2004;38(5):754-6.

27. Kang WL, Wang GR, Wu MY, Yang KY, Er-Tai A, Wu SC, et al. Interferongamma release assay is not appropriate for the diagnosis of active tuberculosis in high-burden tuberculosis settings: A retrospective multicenter investigation. Chin Med J. 2018;131(3):268-75.

28. Khan N, Vidyarthi A, Amir M, Mushtaq K, Agrewala JN. T-cell exhaustion in tuberculosis: pitfalls and prospects. Crit Rev Microbiol. 2017;43(2):133-41.

29. Kim HJ, Yoon HI, Park KU, Lee CT, Lee JH. The impact of previous tuberculosis history on T-SPOT.TB ${ }^{\oplus}$ interferon-gamma release assay results. Int J Tuberc Lung Dis. 2011;15(4):510-6.

30. de Almeida AS, Fiske CT, Sterling TR, Kalams SA. Increased frequency of regulatory $T$ cells and $T$ lymphocyte activation in persons with previously treated extrapulmonary tuberculosis. Clin Vaccine Immunol. 2012;19(1):45-52.

31. Nouailles G, Dorhoi A, Koch M, Zerrahn J, Weiner J, Faé KC, et al. CXCL5secreting pulmonary epithelial cells drive destructive neutrophilic inflammation in tuberculosis. J Clin Invest. 2014;124(3):1268-82.

32. Lam FW, Vijayan KV, Rumbaut RE. Platelets and their interactions with other immune cells. Compr Physiol. 2015;5(3):1265-80.

33. Frojmovic MM, Milton JG. Human platelet size, shape, and related functions in health and disease. Physiol Rev. 1982;62(1):185-261.

34. Blair P. Flaumenhaft R. Platelet alpha-granules: basic biology and clinical correlates. Blood Rev. 2009;23(4):177-89. 
35. de Stoppelaar SF, Van't Veer C, Roelofs JJ, Claushuis TA, de Boer OJ, Tanck MW, et al. Platelet and endothelial cell P-selectin are required for host defense against Klebsiella pneumoniae-induced pneumosepsis. J Thromb Haemost. 2015;13(6):1128-38.

36. Kim EY, Park MS, Kim YS, Kim SK, Chang J, Kang YA. Risk factors for falsenegative results of QuantiFERON-TB gold in-tube assay in non-HIV-infected patients with culture-confirmed tuberculosis. Diagn Microbiol Infect Dis. 2011;70(3):324-9.

37. Bisaso KR, Owen JS, Ojara FW, Namuwenge PM, Mugisha A, Mbuagbaw $L$, et al. Characterizing plasma albumin concentration changes in TB/HIV patients on anti retroviral and anti -tuberculosis therapy. In Silico Pharmacol. 2014;2(1):3.

38. Singanayagam A, Manalan K, Connell DW, Chalmers JD, Sridhar S, Ritchie Al et al. Evaluation of serum inflammatory biomarkers as predictors of treatment outcome in pulmonary tuberculosis. Int J Tuberc Lung Dis. 2016; 20(12):1653-60.

39. Ibrahim MK, Zambruni M, Melby CL, Melby PC. Impact of childhood malnutrition on host defense and infection. Clin Microbiol Rev. 2017; 30(4):919-71.

40. Saucillo DC, Gerriets VA, Sheng J, Rathmell JC, Maciver NJ. Leptin metabolically licenses $T$ cells for activation to link nutrition and immunity. J Immunol. 2014;192(1):136-44.

41. Jacobs SR, Herman CE, Maciver NJ, Wofford JA, Wieman HL, Hammen JJ, et al. Glucose uptake is limiting in T cell activation and requires CD28mediated Akt-dependent and independent pathways. J Immunol. 2008; 180(7):4476-86.

42. Yao S, Huang D, Chen CY, Halliday L, Wang RC, Chen ZW. CD4+ T cells contain early extrapulmonary tuberculosis (TB) dissemination and rapid TB progression and sustain multieffector functions of CD8+ T and CD3lymphocytes: mechanisms of CD4+ T cell immunity. J Immunol. 2014; 192(5):2120-32

43. Kim SH, Song KH, Choi SJ, Kim HB, Kim NJ, Oh MD, et al. Diagnostic usefulness of a T-cell-based assay for extrapulmonary tuberculosis in immunocompromised patients. Am J Med. 2009;122(2):189-95.

44. Wang X, Barnes PF, Dobos-Elder KM, Townsend JC, Chung YT, Shams H, et al. ESAT-6 inhibits production of IFN- $\gamma$ by mycobacterium tuberculosisresponsive human T cells. J Immunol. 2009:182(6):3668-77.

45. Lewinsohn DA, Heinzel AS, Gardner JM, Zhu L, Alderson MR, Lewinsohn DM. Mycobacterium tuberculosis-specific CD8+ T cells preferentially recognize heavily infected cells. Am J Respir Crit Care Med. 2003; 168(11):1346-52.

\section{Publisher's Note}

Springer Nature remains neutral with regard to jurisdictional claims in published maps and institutional affiliations.

Ready to submit your research? Choose BMC and benefit from:

- fast, convenient online submission

- thorough peer review by experienced researchers in your field

- rapid publication on acceptance

- support for research data, including large and complex data types

- gold Open Access which fosters wider collaboration and increased citations

- maximum visibility for your research: over $100 \mathrm{M}$ website views per year

At $\mathrm{BMC}$, research is always in progress.

Learn more biomedcentral.com/submissions 